Psychology of Language and Communication 2012, Vol. 16, No. 1

VERSITNOPEN

DOI: $10.2478 / \mathrm{v} 10057-012-0004-\mathrm{x}$

\author{
NANA BEREKASHVILI \\ Ilia State University, Tbilisi
}

\title{
THE ROLE OF GENDER-BIASED PERCEPTIONS IN TEACHER-STUDENT INTERACTION
}

\begin{abstract}
Differences in teacher perceptions depending on student gender and their impact on teacherstudent interaction was the focus of the study. The questions addressed were: the characteristics that teachers encourage and discourage in girls and boys; the patterns of their responses to students of different genders; perception of pupils' academic achievement, learning skills and giftedness; distribution of attention between girls and boys. The study revealed that in spite of better school results, girls' skills and talents are underestimated, expectations towards them are low and their behavior is restricted to stereotyped feminine roles. The majority of those surveyed support the idea that sex determines different abilities in different learning skills as regards school subjects. While girls, in teachers' opinion, insignificantly exceed boys in the humanities, boys entirely outdo girls in natural sciences and math. Teachers totally deny girls' abilities in sports. At the same time, most teachers are hardly aware of being genderbiased themselves.

Key words: teacher-student interaction, gender biased perceptions, gender differences, expectations
\end{abstract}

\section{Introduction}

The paper highlights the role of secondary school teachers in the formation of gender inequalities in the classroom. Studying the gender-related aspects of teacherstudent interaction is a comparatively new field in Georgian academic research and pedagogic practice, where the role of the agents of socialization, and particularly teachers, in the formation of gender inequalities is underestimated. The mainstream discourse still often voices bio-deterministic and essentialist views about the nature of gender differences in children's abilities and traits. Despite the fact that gender equality in education became a component of the newly adopted Law on Gender Equality, there is no clear understanding what requirements regarding teacher qualifications this implies and what kinds of problems are involved.

Address for correspondence: Nana Berekashvili, Ilia State University, 3/5 Kakutsa Cholokashvili Ave., Tbilisi 0162, Georgia. E-mail: nana.berekashvili.1@iliauni.edu.ge 
New scientific evidence on the correlation of gender-biased stereotypes and expectations and classroom relations between teachers and boy and girl students could lead to a discussion on and better understanding of gender inequalities at school. Therefore it seems most important to analyze in the Georgian educational context what 'gender order' teachers' attitudes represent, to show to what extent traditional gender stereotypes are incorporated in teacher perceptions and everyday teacher-student interactions and to what attribution mistakes they could lead.

There is comprehensive international data manifesting how boys and girls are put in a totally unequal situation through teachers' misperceptions and biased treatment at school (Chapman, 2002). According to Sadker, 'Sitting in the same classroom, reading the same textbook, listening to the same teacher, boys and girls receive very different education' (Sadker, 1999). Adults generally treat children of different sexes differently because they already have stereotyped and differentiated expectations about what is typical for boys and girls (Bem, 1993). It has been well documented that teacher expectations are communicated to students during teacher-student interactions (Good \& Brophy, 1987). Good and Brophy's research shows how teachers give boys more opportunities to generalize and fulfill their ideas compared to girls. Girls receive more instruction in reading exercises, while boys receive special interaction when doing math (Caruthers, 2005). Reay (2001) shows how teachers through their interaction orient their students towards more stereotypical gender schemas: girls are encouraged to be quiet and accurate, while boys are encouraged to think independently and express their ideas and are praised for their activeness. It has been indicated that secondary school teachers tend to negotiate more with boys, criticize them, but also praise boys more often. It has also been shown repeatedly that in classroom processes teachers pay much closer attention to boys than girls (Sadker \& Sadker, 1995; Scott \& McCollum, 1993). These stereotyped expectations and consequent models of teacher-student interaction tend to act as self-sustaining prophecies and shape the qualities and aspirations of students. Considering Rosenthal's findings that 'Teachers appear to teach more and to teach it more warmly to students from whom they have more favorable expectations' (Rosenthal, 1994) and those of Coen (cited in Caruthers, 2005) which also support this view, stating that 'differences in classroom interactions can lead to differences in learning outcomes', it is not surprising that gender-biased expectations result in low self-esteem and modest aspirations in girls (Sadker et al., 1991, Sadker \& Sadker, 1995, Sadker, 1999). However, they determine limitations of choices and areas of development for both genders, result in difference of characteristics of boys and girls, their statuses among peers, their performance and achievement (Shelley, 2000; McCormick, 1995; Carli, 1999). What we see and measure is often the result of children's adjustment to social expectation towards their gender roles (Eagly, 1987). The problem is that when differentiations (manifested in attitudes and behavior) stem from gender stereotypes, they reflect existing gender orders (systems; Connell, R., 1983), where value is placed upon masculine traits and differences are represented in a hierarchical way, and where girls are given a psychologically and socially unfavorable position (Berekashvili, 2011). 
It has been reported that biased perceptions and unequal treatment very often take place without being acknowledged by the teachers (Brophy, 1983). The data also shows that teachers either deny the differences they make or think that the differences are a natural response to divergences that lie in the essence of each gender (Chapman, 2002).

\section{Research objectives}

Based on the aforementioned manifestations of inequalities and taking into account the lack of elaboration of the problem in the Georgian education system, the present study focuses on the following objectives: a) Revealing perceptions and expectations among teachers that underline and support gender inequalities in their interaction with students; b) Studying the areas, character and vector of gender-based differentiation; c) Examining to what extent gender bias is acknowledged by teachers.

\section{Method}

Based on the results of 6 focus groups conducted with the participation of school teachers, a multi-scale attitude questionnaire was developed including the following aspects of gender differentiation: Reasons for and means of encouragement (approval) and punishment (disapproval) of boys and girls; Assessment of capabilities of boys and girls; The amount of teacher attention given to each gender. The questionnaire consisted of 104 closed-type questions, combined in 5 blocks (scales) named for convenience: approval scale, punishment scale, reaction scale, learning skills block, attention scale. The first 3 scales were designed in a symmetric way, formulating the same questions regarding boys and girls. E.g.: 'What kind of bad behavior do you punish girls/boys for in the first, second and third place?' (the options were provided). Based on the results of 51 respondents, the reliability of the questionnaire was examined during the pilot stage. The Cronbach's alpha for the different scales was: 0.928 for the 'approval' scale; 0.936 for the 'punishment' scale; 0.933 for the 'reaction' scale; 0.944 for the 'learning skills' scale; and 0.947 for the 'attention' scale.

Participants: The questionnaire was administered to 186 secondary school teachers of 5-7 grade classes, from the capital and 4 other cities of Georgia in the school environment with the research assistant attending.

\section{Results}

\section{Characteristics that teachers encourage/approve in boys and girls}

Table 1 presents a comparison of the means of the answers starting with 1 (maximum importance) and finishing with 3 (less important), the lower the indicator value, the higher the level of approval of the characteristic. 
Table 1. Characteristics that teachers encourage in girls and boys

\begin{tabular}{|c|c|c|c|c|c|}
\hline Characteristics & Group & Mean & $\mathrm{SD}$ & $\mathrm{t}$ & $\mathrm{p}$ \\
\hline \multirow[t]{2}{*}{ General education } & Girls & 1.28 & 0.572 & \multirow{2}{*}{1.207} & \multirow{2}{*}{0.228} \\
\hline & Boys & 1.22 & 0.477 & & \\
\hline \multirow[t]{2}{*}{ Knowing the subject well } & Girls & 1.92 & 0.730 & \multirow{2}{*}{0.616} & \multirow{2}{*}{0.539} \\
\hline & Boys & 1.88 & 0.719 & & \\
\hline \multirow[t]{2}{*}{ Accurate ${ }^{* * *}$} & Girls & 1.12 & 0.369 & \multirow{2}{*}{4.118} & \multirow{2}{*}{0.000} \\
\hline & Boys & 1.31 & 0.498 & & \\
\hline \multirow[t]{2}{*}{ Avoiding conflicts } & Girls & 1.48 & 0.668 & \multirow{2}{*}{0.131} & \multirow{2}{*}{0.896} \\
\hline & Boys & 1.49 & 0.671 & & \\
\hline \multirow[t]{2}{*}{ Taking care of others } & Girls & 1.58 & 0.711 & \multirow{2}{*}{0.519} & \multirow{2}{*}{0.604} \\
\hline & Boys & 1.54 & 0.686 & & \\
\hline \multirow[t]{2}{*}{ Obedient } & Girls & 1.74 & 0.736 & \multirow{2}{*}{0.192} & \multirow{2}{*}{0.848} \\
\hline & Boys & 1.75 & 0.711 & & \\
\hline \multirow[t]{2}{*}{ Active during the lesson } & Girls & 1.56 & 0.688 & \multirow{2}{*}{0.347} & \multirow{2}{*}{0.729} \\
\hline & Boys & 1.58 & 0.647 & & \\
\hline \multirow[t]{2}{*}{ Independently thinking* } & Girls & 1.27 & 0.546 & \multirow{2}{*}{2.212} & \multirow{2}{*}{0.028} \\
\hline & Boys & 1.15 & 0.418 & & \\
\hline \multirow[t]{2}{*}{ Patriotic* } & Girls & 1.27 & 0.564 & \multirow{2}{*}{2.471} & \multirow{2}{*}{0.014} \\
\hline & Boys & 1.14 & 0.448 & & \\
\hline \multirow[t]{2}{*}{ Believes in God } & Girls & 1.41 & 0.657 & \multirow{2}{*}{0.113} & \multirow{2}{*}{0.910} \\
\hline & Boys & 1.40 & 0.668 & & \\
\hline \multirow[t]{2}{*}{ Free ${ }^{* * *}$} & Girls & 1.90 & 0.865 & \multirow{2}{*}{3.020} & \multirow{2}{*}{0.003} \\
\hline & Boys & 1.62 & 0.76 & & \\
\hline Self-assured & Girls & 1.74 & 0.774 & 1841 & 0067 \\
\hline & Boys & 1.58 & 0.74 & 1.01 & \\
\hline Having masculine/feminine & Girls & 1.47 & 0.742 & & \\
\hline qualities $* * *$ & Boys & 1.22 & 0.572 & 3.541 & 0.000 \\
\hline
\end{tabular}

Note: ${ }^{*} \mathrm{p}<0.05,{ }^{* *} \mathrm{p}<0.01,{ }^{* *} \mathrm{p}<0.001$

The highest gender differences in characteristics were found regarding accurate, where girls exceed boys $(\mathrm{p}=0.000)$; free, which scored higher desirability for boys $(\mathrm{p}=0.003)$; having masculine qualities is perceived by teachers as more desirable than having feminine qualities $(\mathrm{p}=0.000)$. Independent thinking, patriotic, self-assured are also qualities that are significantly more encouraged in boys $(\mathrm{p}=0.028 ; \mathrm{p}=0.014$; $\mathrm{p}=0.067$ at the edge of statistical significance). 
Table 2. Kinds of 'misbehavior' for which teachers punish boy and girl students

\begin{tabular}{|c|c|c|c|c|c|}
\hline Kinds of misbehavior & Group & Mean & SD & $\mathrm{t}$ & $\mathrm{p}$ \\
\hline \multirow[t]{2}{*}{ Lack of attention during lessons } & Girls & 1.93 & 0.688 & \multirow{2}{*}{0.000} & \multirow{2}{*}{1.000} \\
\hline & Boys & 1.93 & 0.688 & & \\
\hline \multirow[t]{2}{*}{ Laziness } & Girls & 1.79 & 0.696 & \multirow{2}{*}{-0.601} & \multirow{2}{*}{0.549} \\
\hline & Boys & 1.82 & 0.700 & & \\
\hline \multirow[t]{2}{*}{ Rudeness } & Girls & 1.06 & 0.306 & \multirow{2}{*}{1.873} & \multirow{2}{*}{0.063} \\
\hline & Boys & 1.13 & 0.381 & & \\
\hline \multirow{2}{*}{$\begin{array}{l}\text { Causing commotion in the } \\
\text { classroom * }\end{array}$} & Girls & 1.30 & 0.540 & \multirow{2}{*}{1.955} & \multirow{2}{*}{0.052} \\
\hline & Boys & 1.23 & 0.448 & & \\
\hline \multirow[t]{2}{*}{ Disobedience } & Girls & 1.68 & 0.757 & \multirow{2}{*}{0.961} & \multirow{2}{*}{0.338} \\
\hline & Boys & 1.63 & 0.695 & & \\
\hline \multirow[t]{2}{*}{ Verbal offence } & Girls & 1.35 & 0.539 & \multirow{2}{*}{0.000} & \multirow{2}{*}{1.000} \\
\hline & Boys & 1.35 & 0.592 & & \\
\hline \multirow[t]{2}{*}{ Physical offence } & Girls & 1.18 & 0.427 & \multirow{2}{*}{-0.865} & \multirow{2}{*}{0.388} \\
\hline & Boys & 1.21 & 0.527 & & \\
\hline \multirow[t]{2}{*}{ Lies* } & Girls & 1.37 & 0.645 & \multirow{2}{*}{1.272} & \multirow{2}{*}{0.205} \\
\hline & Boys & 1.43 & 0.626 & & \\
\hline \multirow[t]{2}{*}{ Damaging school property } & Girls & 1.88 & 1.810 & \multirow{2}{*}{1.350} & \multirow{2}{*}{0.179} \\
\hline & Boys & 1.69 & 0.758 & & \\
\hline \multirow[t]{2}{*}{ Grabbing others' possession } & Girls & 1.41 & 0.635 & \multirow{2}{*}{0.506} & \multirow{2}{*}{0.614} \\
\hline & Boys & 1.39 & 0.622 & & \\
\hline \multirow[t]{2}{*}{ Missing lessons } & Girls & 1.80 & 0.766 & \multirow{2}{*}{0.308} & \multirow{2}{*}{0.759} \\
\hline & Boys & 1.79 & 0.763 & & \\
\hline \multirow[t]{2}{*}{ Smoking cigarettes * } & Girls & 1.36 & 0.623 & & \\
\hline & Boys & 1.54 & 0.741 & 3.462 & 0.001 \\
\hline
\end{tabular}

Note: ${ }^{*} \mathrm{p}<0.05,{ }^{* *} \mathrm{p}<0.01,{ }^{* * *} \mathrm{p}<0.001$

\section{Kinds of bad behavior teachers punish boys and girls for}

As seen from Table 2, the results do not point to a substantial gender-based difference in reasons for punishment. Three reasons for punishment mentioned by teachers that differ for boys and girls significantly are: causing commotion in the classroom ( $\mathrm{p}=0.052)$, which is more strongly punished in boys, smoking cigarettes in school ( $\mathrm{p}=0.001)$, for which teachers punish girls more, and rudeness $(\mathrm{p}=0.063$, the edge of significance), which is again strongly punished in girls. 
Table 3. Who has better marks (in teachers' perception)

\begin{tabular}{lcc}
\hline Type of answer & N & Valid percent \\
\hline Girls better & 98 & 57.3 \\
Boys better & 9 & 5.3 \\
Equally & 64 & 37.4 \\
Hesitate to answer & 15 & \\
Total & 186 & 100.0 \\
\hline
\end{tabular}

Note: $\chi^{2}=70.772 ; \mathrm{p}=0.000$

Is there any difference in the types of teachers' reactions to their girl and boy students' bad behavior?

According to the results, among 11 different kinds of reactions, teachers report three that differ significantly regarding girls' and boys' misbehavior. These are: "reprimand", "making students change their seats" and "being reported to the school principal". In all three cases these reactions/strategies are used mostly for boys ( $\mathrm{p}=0.037 ; \mathrm{p}=0.040 ; \mathrm{p}=0.000$ respectively).

In teachers' opinion, how boys and girls differ in marks, learning skills and giftedness

The results indicate that while teachers have comparatively objective criteria to say that girls have better marks where girls exceed boys, in the other two measures (skills and giftedness) teachers can express a more speculative attitude. As seen from Table 3, while $34.4 \%$ indicate that there is no difference between girls' and boys' marks, others are inclined to see girls exceeding boys significantly $(52.7 \%$, $4.8 \%$ respectively).

As for learning skills and giftedness (Tables 4 and 5), the majority (56.5\%, 40.3 respectively) attribute these merits equally to students of both sexes. However,

Table 4. Difference in learning skills between boys and girls (in teachers' perception)

\begin{tabular}{lll}
\hline Type of answer & $\mathrm{N}$ & Valid percent \\
\hline Girls better & 8 & 4.7 \\
Boys better & 59 & 34.3 \\
Equally & 105 & 61.0 \\
Hesitate to answer & 11 & \\
Total & 172 & 100.0 \\
\hline
\end{tabular}

Note: $\chi^{2}=82.128 ; \mathrm{p}=0.000$ 
Table 5. Difference in giftedness (in teachers' perception)

\begin{tabular}{lcc}
\hline Type of answer & $\mathrm{N}$ & Valid percent \\
\hline Girls better & 6 & 3.4 \\
Boys better & 63 & 39.0 \\
Equally & 71 & 79.1 \\
Hesitate to answer & 37 & 89.8 \\
Total & 177 & 100.0 \\
\hline
\end{tabular}

Note: $\chi^{2}=97.887 ; \mathrm{p}=0.000$

the rest attribute them to boys, denying girls' potential to succeed at school. The differences between "boys", "girls" and "equally" for all 3 measures are statistically significant: $\mathrm{p}=0.000$ for academic achievements/marks; $\mathrm{p}=0.000$ for learning skills and $\mathrm{p}=0.000$ for giftedness.

\section{Advantage in learning skills in teachers' perception}

Table 6 presents a significant discrepancy in how teachers perceive their students' various learning skills depending on their gender. While, according to teachers' opinion, girls outdo boys in such learning skills as reading $(\mathrm{p}=0.000)$, writing $(\mathrm{p}=0.000)$, creative use of materials $(\mathrm{p}=0.000)$ and use of previous materials, boys

Table 6. Attribution of the advantage in learning skills to boys and girls

\begin{tabular}{lccccc}
\hline Learning skills & Boys & Girls & Equally & $\chi^{2}$ & $\mathrm{p}$ \\
\hline Reading & $\%$ & $\%$ & $\%$ & & \\
Writing & 18.6 & 46.2 & 35.3 & 62.792 & 0.000 \\
Interesting essay & 1.7 & 78.2 & 20.1 & 253.033 & 0.000 \\
Creative use of materials & 24.7 & 28.9 & 46.4 & 147.538 & 0.000 \\
Generalization & 18.0 & 35.6 & 46.6 & 97.285 & 0.000 \\
Quick counting & 39.1 & 14.6 & 46.4 & 87.285 & 0.000 \\
Quick answer & 73.9 & 4.8 & 21.2 & 182.072 & 0.000 \\
Correct answer & 52.2 & 22.4 & 25.5 & 49.564 & 0.000 \\
Original answer & 26.0 & 27.9 & 45.5 & 69.801 & 0000 \\
Use of previous material & 35.7 & 14.7 & 49.7 & 82.337 & 0.000 \\
Deep comprehension of materials & 36.0 & 33.2 & 46.9 & 86.818 & 0.000 \\
Memorizing materials & 36.1 & 27.0 & 41.7 & 86.818 & 0.000 \\
\hline
\end{tabular}


Figure 1. Teachers' opinion about advantages of boys and girls in different learning skills Ponadto w rysunku: generalisation - generalization, count - counting

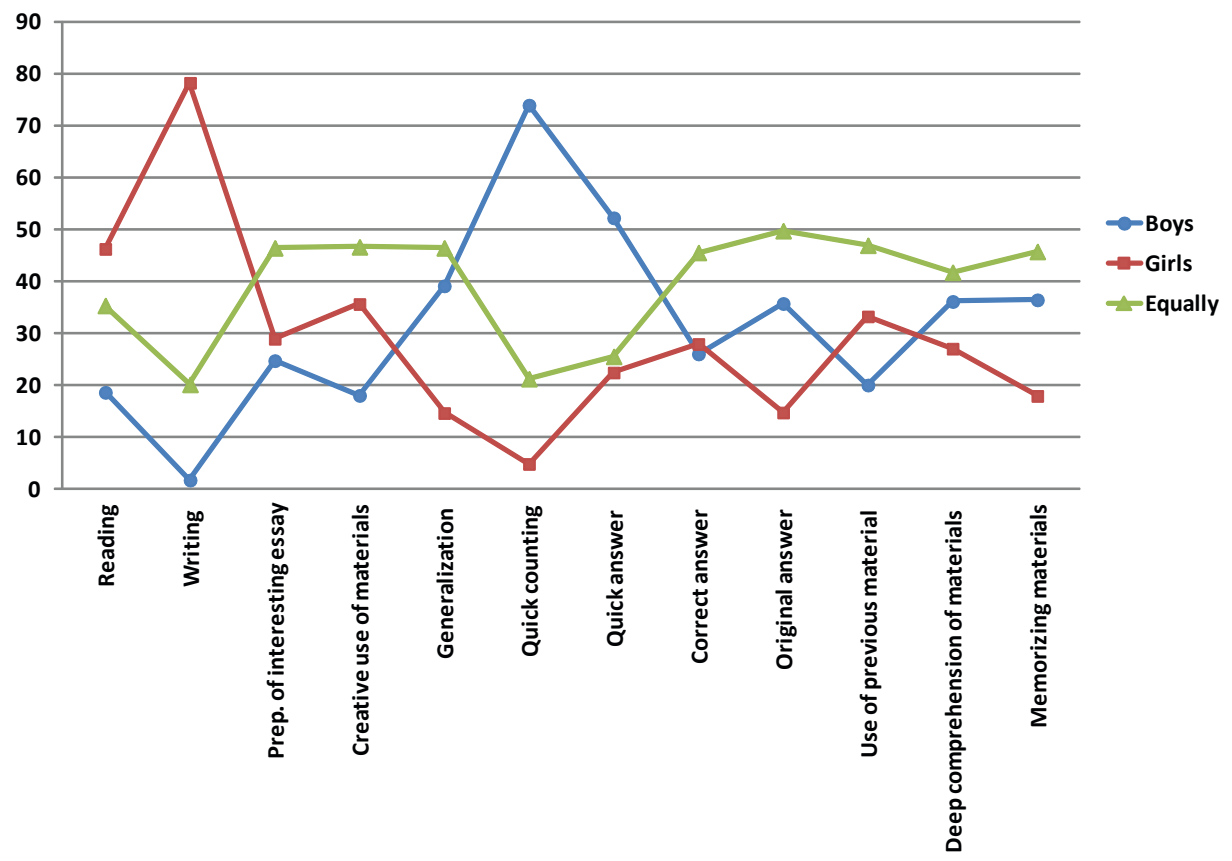

outscore girls in skills associated with smartness, comprehension and originality, such as: generalization, quick counting, quick answer, original answer.

How teachers assess boys' and girls' efficiency in school subjects

With the exception of social sciences, the majority of teachers' answers indicate a tendency to associate school subjects with the sex of the student. Figure 5 shows that girls are estimated very low in their talents for math and sports and accordingly, in $82.8 \%$ and $82.6 \%$ of answers these talents are ascribed to boys. On the other hand, boys' talents for languages and arts score very low (6.6\% and $5.8 \%$ respectively). The results also specify that boys exceed girls significantly in natural sciences, yet here we have also received a high score of 'equally' answers. The differences within all answers in all 6 categories are statistically significant $(\mathrm{p}=0.000)$.

\section{To whom teachers' attention is addressed}

In this category the answer "equally" significantly prevails over others. However, comparing the answers 'more to boys' and 'more to girls', we observe 
Figure 2. Teachers' perception of boys' and girls' efficiency in different school subjects

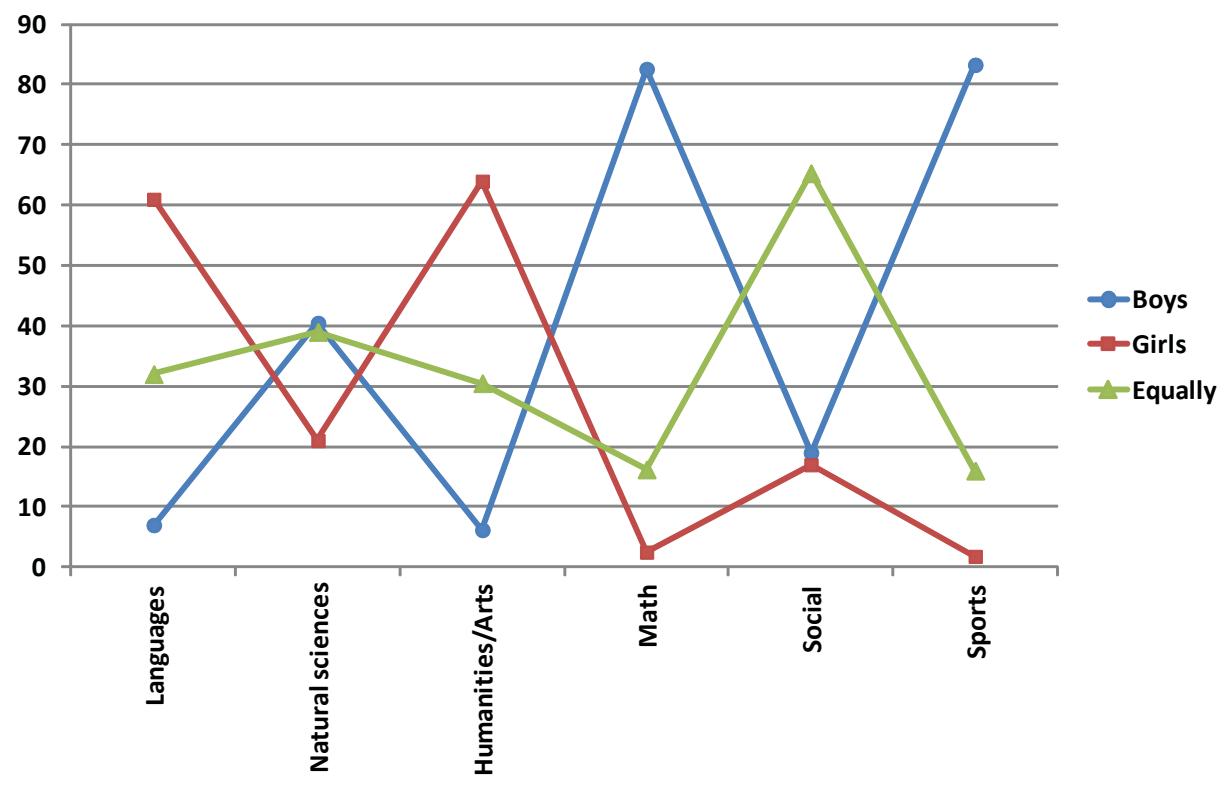

significant differences. This is especially true regarding attention during break: while $40.9 \%$ of teachers think they distribute attention equally, $53 \%$ admit that they focus their attention on boys and only $4.9 \%$ pay more attention to girls. Likewise, boys get comparatively more attention while presenting materials, during group discussion and giving homework. Girls get more attention only during the 'homework check'.

Table 7. To whom teachers' attention is addressed during teaching processes

\begin{tabular}{lccccc}
\hline Teaching process & Boys & Girls & Equally & $\chi^{2}$ & $\mathrm{p}$ \\
\hline Presenting material & 19.8 & 2.3 & 76.7 & 260.558 & 0.000 \\
Homework check & 12.6 & 15.6 & 70.7 & 193.359 & 0.000 \\
Group discussion & 18.9 & 5.7 & 74.3 & 238.554 & 0.000 \\
Giving homework & 20.2 & 8.3 & 70.2 & 195.810 & 0.000 \\
During break & 53.0 & 4.9 & 40.9 & 131.756 & 0.000 \\
\hline
\end{tabular}




\section{Discussion}

The study reports various aspects of gender-based differentiation in Georgian teachers' perceptions, expectations and behavioral patterns. It seems that gender stereotypes substantially influence the tendency to differentiate students on the basis of sex. They approve of gender stereotypical characteristics or disapprove of those that contradict them. Thus accuracy is encouraged in girls, while for boys independent thinking, being patriotic and self-assured are more encouraged characteristics compared to girls. This differentiation reflects the content of the gender stereotypes, where qualities associated with independence, strong ego and activity are attributed to men/boys and where masculine characteristics are seen as a general standard for humankind and accordingly valued more than feminine ones (Bem, 1993). Although not many differences were reported regarding reasons for punishment, those that were significant also tend to reflect traditional gender stereotypes. For example, smoking cigarettes in school is a misbehavior for which teachers punish girls more. Apart from being inappropriate and harmful for children, in Georgian culture smoking is considered inappropriate for decent women. The influences of gender-biased perceptions were similarly demonstrated in Reay's study (2001), where different behaviors were tolerated in boys than in girls because they were considered inconsistent to women's role.

There are a few significant differences among the 11 different kinds of reactions regarding girls' and boys' misbehavior. They are: "reprimand", "making students change their seats" and "being reported to the school principal". All three reactions/ strategies are used mostly for boys. These results found support in, for instance, Good and Findley's (1985) data reporting that boys receive more feedback, both positive and negative, and more diversified reactions from teachers.

The results have shown that assessment of children's capabilities is the field where teachers' gender bias is manifested in full. While teachers admit that girls have better marks than boys as 9 to 1 , about half of the surveyed teachers think that boys have better learning skills and are more gifted. Girls seem to be practically denied having good learning skills or being more gifted. These distinctions are well expressed in the columns in Figure 3.

These assessments found similarities with Sadker et al.'s (1991) findings which reflect sex-differentiated expectations of teachers according to which teachers told boys that 'they did not do well because they did not try hard enough', whereas the connection between effort and outcome was rarely made with girls. Likewise, in Hallinan and Sørensen's (1987) research, even when boys and girls had similar scores, boys were assigned to the highest ability groups.

Attribution of different learning skills to genders is also an obvious trend: teachers give priority to boys in learning skills that are associated with smartness, deep comprehension and originality, thus representing higher-level cognitive operations. Girls' advantages are seen in reading, writing and 'dealing with learning 
Figure 3. Distribution in the answers 'equally', 'girls more' (or better), and 'boys more' (or better) regarding academic achievements, learning skills and giftedness

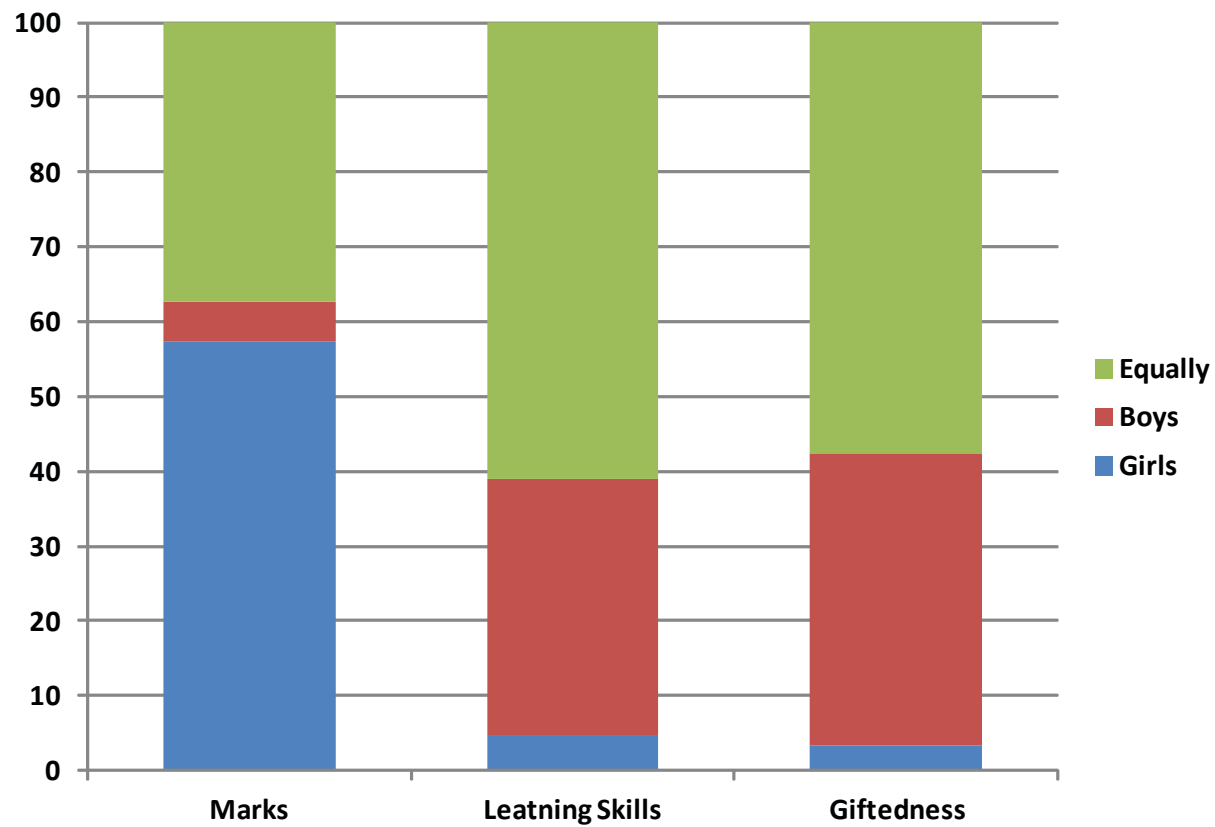

materials'. These gender-related asymmetries in assessment are notably shaped by stereotyped expectations about what is typical for boys and girls, a problem which is discussed in Good and Findley's work (1985).

The results are meaningful in both cases - whether they reflect the true picture of differences between boys and girls in the development of learning skills at this age, and here we can suggest the phenomenon of a self-sustaining prophecy. But they are also significant if they reflect only teachers' gender bias in assessment. In both cases they indicate gaps in education and lack of attention to signs of inequality.

It seems that teachers believe that students of different sexes possess very different talents for all school subjects with the exception of social sciences. Georgian teachers strongly tend to associate school subjects with different genders: while girls are perceived as skillful in the humanities and arts, they are denied any talents for math and sports. Boys are seen as skillful in math, natural sciences and sports, but quite undeveloped in languages and the humanities.

When measuring the distribution of teachers' attention in specific classroom processes, there is also a clear bias towards boys. These findings are supported by the research of Eccles and Blumenfeld, who reported that teachers initiate 10 
percent more communicational attention, strengthening boys' sense of dominance and importance (Eccles \& Blumenfeld, 1985). It appears that girls get more attention only during the 'homework check', which is also in accordance with Sadker et al.'s (1991) finding that the completion of a task is the orientation teachers use to give to girls. We can also highlight that gender bias was hardly or not at all acknowledged by teachers. The answer "I give my attention to students of both genders equally" significantly prevails over others. This result matches Sadker's studies according to which teachers believe they treat students equally and deny gender bias in their own behavior (Sadker \& Sadker, 1991).

Thus the study proves the persistence of gender-stereotyped expectations and respective interactional patterns among Georgian teachers. The gender-related differentiation that is practiced by a significant group of teachers tends to promote gender inequality in the classroom, undervalues girls' abilities and builds a basis for further gender differentiation. At the same time the results point to gaps which can be addressed through teacher training. Therefore they can be considered as a resource for understanding the problems and for rethinking educational strategies to achieve a more gender equitable school environment.

\section{References}

Bem, S.L. (1993). The lenses of gender. Transforming the debate on sexual inequality. New Haven, CT: Yale University Press.

Berekashvili, N. (2011). Gender bias in Georgian school teachers' attitudes and behavior. In XV European Conference on Developmental Psychology ECDP (pp. 465-474.). Bologna: Medimond International Proceeding.

Brophy, J. (1983). Research on the self-fulfilling prophecy and teacher expectations. Journal of Education Psychology, 75 (5), 631-661.

Carli, L.L. (1999). Gender, interpersonal power, and social influence. fournal of Social Issues, 55 (1), 81-99.

Caruthers, L. (2005). Classroom interactions and achievement. Mid-Atlantic Research for Education \& Learning. Retrieved from: http://www.mcrel.org/ products/noteworthy/noteworthy/loycec.asp

Chapman, A. (2002). Gender Bias in Education. Research Room. Retrieved from: http://www.edchange.org/multicultural/papers/genderbias.html

Connell, R.W. (1983). Which way is up? Essays on sex, class and culture. Sydney: George Allen \& Unwin.

Eagly, A.H. (1987). Sex differences in social behavior. A social-role interpretation. Hillside, NJ: Lawrence Erlbaum Associates.

Ecclees, J. \& Blumenfeld, P. (1985). Classroom experiences and student gender: Are there differences and do they matter? In L.C. Wilkinson \& C.B. Marret (Eds.), Gender influences in classroom interaction (pp. 79-114). Orlando, FL: Academic Press. 
Good, T.L. \& Brophy, J.E. (1987). Looking in classrooms. New York: Harper \& Row. Good, T.L. \& Findley, M.J. (1985). Sex role expectations and achievement. In J.B. Dusek (Ed.), Teacher expectancies (pp. 271-294). Hillsdale, NJ: Erlbaum.

Hallinan, M.T. \& Sørensen, A.B. (1987). Ability grouping and sex differences in mathematics achievement. Sociology of Education, 60 (2), 63-72.

McCormick, P. (1995). Are girls taught to fail? U.S. Catholic, 60 (2), 38-42.

Rosenthal, R. (1994). Interpersonal expectancy effects: A 30-year perspective. Current Directions in Psychological Science, 3, 176-179.

Sadker, D. (1999). Gender equity: Still knocking at the classroom door. Educational Leadership, 56 (7), 22-26.

Sadker, M. \& Sadker, D. (1995). Failing at fairness: How our schools cheat girls. New York: Simon and Schuster.

Sadker, M., Sadker, D., \& Klein, S. (1991). The issues of gender bias in elementary and secondary education. The Review of Research in Education, 17 (7), 269-334

Scott, E. \& McCollum, H. (1993). Making it happen: Gender equitable classrooms. In S.K. Biklen \& D. Pollard (Eds.), Gender and Education. Part 1 (pp. 174-190). Chicago: University of Chicago Press.

Reay, D. (2001). 'Spice Girls,' 'Nice Girls', 'Girlies', and 'Tomboys': Gender discourses, girls' cultures and femininities in the primary classroom. Gender and Education, 13 (2), 153-166.

Shelley S.S. (2000). The relationship among teacher expectations, teacher attitudes toward the TAAS, and student achievement. Denton, TX: University of North Texas. Retrieved from: http://digital.library.unt.edu/ark:/67531/metadc2691/ $\underline{\mathrm{m} 2 / 1 / \text { high_res d/Dissertation.pdf }}$ 
